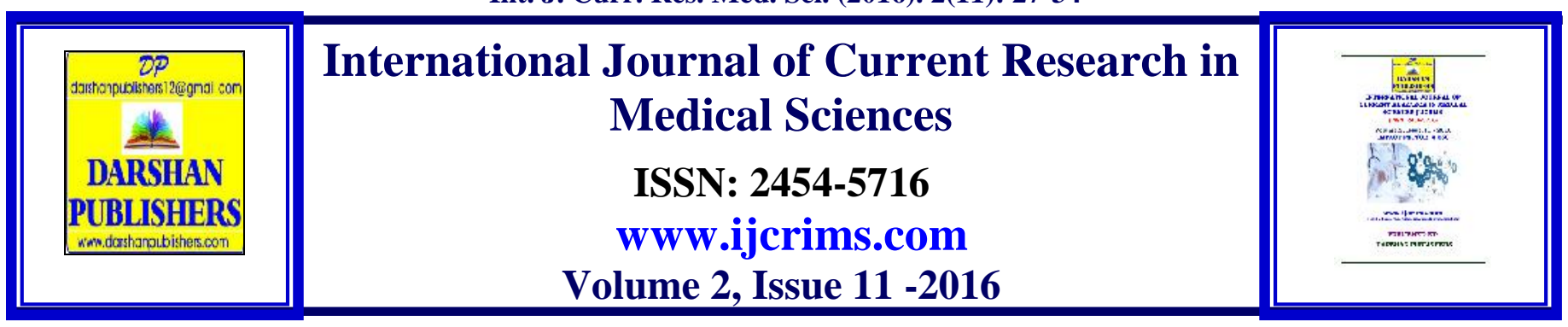

\title{
Risk factors of differentiated thyroid cancer in Sohag, Egypt
}

\author{
Rasha Abd Elhameed Ali Mohamed*, Raafat Abd Elaal Backeet**, \\ Wafaa Abd Elhameed Elsaayed*** \\ *Lecturer of Public Health \& Community Medicine \\ **Lecturer of Oncology \\ *** Lecturer of Nuclear Medicine \\ *Corresponding author: rashaali815@yahoo.com
}

\begin{abstract}
Introduction: Two folds increase in differentiated thyroid cancer (DTC) have been noticed in the past few decades. This might be linked to either increase in the exposure of individuals to environmental risk factors or improved diagnostic techniques or both of them. We aimed at studying risk factors of thyroid cancer in Sohag, Egypt. Methodology: retrospective case control study that was conducted in Oncology \& Nuclear department of Sohag University Hospital in four months duration from July 2016 to October 2016.105 DTC cases were compared to 150 controls for presence of these risk factors (radiation, radioactive iodine, obesity, family history of thyroid cancer, previous thyroid nodule and smoking). Results: out of 105 DTC cases, 94.1\% were females, $60.2 \%$ had papillary carcinoma. Compared to controls, obesity and positive history of thyroid nodule were found to be very high significant risk factors ( $\mathrm{P}$ value $<0.001$ ), residence also showed significant difference between cases and control ( $\mathrm{P}$ value $<0.05$ ). While no significant difference was found as regard smoking and positive family history of thyroid cancer. Conclusion: Ultra sonographic finding should be the corner stone in management of thyroid nodule in any patient whatever the age and increase awareness about hazards of obesity are needed especially among uneducated rural females.
\end{abstract}

Key words: differentiated thyroid cancer, risk factors.

\section{Introduction}

Thyroid carcinoma (TC) is a neoplasm derived from the thyroid tissue. According to the World Cancer Report 2014, thyroid cancer is one of the less frequent cancers worldwide (Stewart BW and Wild, 2014). Although it is the most prevalent endocrine malignancy particularly its differentiated type (Jemal et al., 2010) However its incident showed exponential increase over the past years through the worldwide with a wide geographic variation (Jemal et al., 2009). It is estimated that two fold increase in thyroid cancer occurred over the past few decades. Much of this is attributable to improved detection of the disease by thyroid ultrasound and ultrasound-guided fine needle aspiration rather than an increase in occurrence (Stewart BW and Wild, 2014) and (Wartofsky L, 2010). However this cannot explain the whole observed increase as there has been an increase in the incidence of not only small, clinically insignificant tumors but also larger, clinically significant tumors. (Xu L et al., 2020). 
In Egypt, According to the National Cancer Registry Program, thyroid cancer is the fifth most frequent cancer in females accounting for $3.6 \%$ of all malignancy in women. With an incidence that ranged between $3.5 \%$ in upper Egypt in 2008 to $3.9 \%$ in 2011 in lower Egypt. The estimated number of thyroid cancer in Egypt in 2015 was 2448 cases of whom 1876 were females (Amal et al., 2014).

Most thyroid cancers are epithelial in origin. The most common histopathological type is papillary (50-80\% of cases) followed by follicular (15-20\% of cases), both are considered highly differentiated thyroid cancer (Brindel et al., 2010) Differentiated thyroid cancer have good prognosis with $90 \%-95 \%$ of ten years survival. Thyroid cancer has a lower fatality rate than most cancers (Hu et al., 2008).

Substantial variations in thyroid cancer incidence in the world strongly implicate environmental factors in the etiology of this cancer. Until recently, the only well-established risk factor for DTC was exposure to ionizing radiation during childhood and adolescence, but this is thought unlikely to have been a major population attributable risk factor, because few patients with DTC have a known history of radiation exposure (Carter et al., 2011). Female gender, benign thyroid nodule are suggested risk factors for thyroid cancer. Moreover several lifestyle factors have been found by many observational studies to be associated with the risk of thyroid cancer as diet low in iodine, obesity, cigarette smoking, alcohol consumption (Zhao et al., 2012) and (Kitahara et al., 2012).

This study aims at studying environmental risk factors of differentiated thyroid cancer (DTC) in Sohag, Egypt.

\section{Patients and Method}

Study type: This is retrospective hospital based case control study conducted in the Oncology \& Nuclear department of the Faculty of Medicine, Sohag University. The study was conducted during four months duration that extended from July 2016 to October 2016. All confirmed cases of differentiated thyroid cancer that came to the department for follow up during the study period were asked to participate in the study. Enrolled cases of DTC were compared with age and sex matched control group for the presence of risk factors.

\section{Study population:}

The cases: The thyroid cancer cases were defined based on the International Classification of Diseases for Oncology (ICD-O) (code C73) inclusion criteria were any case of confirmed diagnosis of cancer thyroid above 18 years old that accepted to participate in the study. These cases were histopathologically confirmed for the diagnosis of differentiated thyroid cancer. Informed consents were obtained from the patients. 105 cases of differentiated thyroid cancer accepted to participate in the current study. Data about age, sex, histological type, multifocality of the lesion, 1st dose of radioactive iodine, lymph node metastasis and follow up results were gathered from DTC cases by the researcher.

DTC cases were compared to 150 age and sex matched healthy control group free from thyroid cancer as regard presence of risk factors under the study. These study subjects were interviewed face to face by the researcher where data about (residence, family history of DTC, history of irradiation in childhood, history of exposure to radioactive iodine, positive history of other thyroid nodule (lesion), weight and height and calculation of BMI, cigarette smoking and alcohol consumption) were gathered from both cases and controls.

\section{Statistical analysis}

Statistical Package for the Social Science (SPSS) program (version 20) was used for grouping, tabulation and statistical analysis of the data. Sample characteristics were summarized using the mean and the standard deviation (SD) for continuous variables and percentage for categorical variables. Chi square test was used to compare distributions of characteristics between case and control groups as appropriate and $P$ value below 0.05 was considered significant. 
Int. J. Curr. Res. Med. Sci. (2016). 2(11): 27-34

Conditional logistic regression models were used to calculate odds ratios (ORs) and 95\% confidence intervals (CIs) associated with the studded risk factors.

\section{Results}

We successfully enrolled 105 (DTC) patients and 150 cancer free controls in this case control study. The mean age of the enrolled cases was 49.4 years, $94 \%$ of them were females, and papillary cancer cases represented $60 \%$ of cases. $61 \%$ ofthem live in rural areas (table1).

Table (1) Sociodemographic and clinico pathological features of the studded cases of DTC:

\begin{tabular}{|c|c|}
\hline Variable & $\begin{array}{c}\text { Summary statistical } \\
(\mathbf{n}=\mathbf{1 0 5})\end{array}$ \\
\hline $\begin{array}{l}\text { Age } \\
<45 \\
\geq 45 \\
\text { Mean (SD) }\end{array}$ & $\begin{array}{l}36(34.2 \%) \\
69(65.8 \% \\
49.4(1.18)\end{array}$ \\
\hline $\begin{array}{l}\text { Gender } \\
\text { Females } \\
\text { Males }\end{array}$ & $\begin{array}{c}99(94.1 \%) \\
6(5.3 \%)\end{array}$ \\
\hline $\begin{array}{l}\text { Residence } \\
\text { Rural } \\
\text { Urban }\end{array}$ & $\begin{array}{c}63(61.1 \%) \\
40(39.9)\end{array}$ \\
\hline $\begin{array}{l}\text { Duration from firstly diagnosed } \\
\text { Mean (SD) }\end{array}$ & $5.8 y(2.27)$ \\
\hline $\begin{array}{l}\text { Histological type } \\
\text { Papillary } \\
\text { Follicular }\end{array}$ & $\begin{array}{l}62(60.2 \%) \\
41(39.8 \%)\end{array}$ \\
\hline $\begin{array}{l}\text { Follow up results } \\
\text { Free } \\
\text { Recurrence } \\
\text { Lymph node metastasis } \\
\text { Bone metastasis }\end{array}$ & $\begin{array}{c}94(91.2 \%) \\
3(2.9 \%) \\
2(1.9 \%) \\
1(0.97 \%)\end{array}$ \\
\hline $\begin{array}{l}\text { Lymph node metastasis } \\
\text { Positive } \\
\text { Negative }\end{array}$ & $\begin{array}{l}81(77.1 \%) \\
24(22.9 \%)\end{array}$ \\
\hline $\begin{array}{l}\text { Multifocal tumor } \\
\text { Unifocal tumor }\end{array}$ & $\begin{array}{l}60(57.1 \%) \\
45(42.9 \%)\end{array}$ \\
\hline
\end{tabular}

(Table 2) shows distribution of DTC cases and cancer free controls as regard the studded risk factors, being overweight or obese and having positive history of previous thyroid nodule increased risk of thyroid cancer in the cases and the estimated Odds Ratio (OR) is 11.3 with $95 \%$ CI 6.234 to 20.715 and OR 95.897 with $95 \%$ CI 28.745 to 319 respectively. Statistically significant difference is present between cases and controls as regard residence $(\mathrm{P}$ value $=0.013)$. 
Int. J. Curr. Res. Med. Sci. (2016). 2(11): 27-34

Table (2): comparison between DTC cases and cancer free control in both sexes as regard the studded risk factors.

\begin{tabular}{|c|c|c|c|c|c|}
\hline Characteristics & $\begin{array}{l}\text { Control } \\
(n=149) \\
\text { No }(\%)\end{array}$ & $\begin{array}{c}\text { DTC cases } \\
(\mathrm{n}=105) \\
\text { No }(\%)\end{array}$ & $\begin{array}{l}\text { Odds } \\
\text { ratio }\end{array}$ & 95\% CI & $P$ value \\
\hline $\begin{array}{l}\text { Residence } \\
\text { Rural } \\
\text { Urban }\end{array}$ & $\begin{array}{l}106(70.6 \%) \\
43(29.4 \%)\end{array}$ & $\begin{array}{l}63(60 \%) \\
42(40 \%)\end{array}$ & 1.643 & $0.970-2.784$ & 0.013 \\
\hline $\begin{array}{l}\text { Family history } \\
\text { Positive } \\
\text { Negative }\end{array}$ & $\begin{array}{l}24(16.2 \%) \\
125(83.8 \%)\end{array}$ & $\begin{array}{l}18(20 \%) \\
87(80 \%)\end{array}$ & 1.078 & $0.552-2.105$ & 0.827 \\
\hline $\begin{array}{l}\text { Obesity } \\
\text { BMI } \geq 25 \\
\text { BMI }<25\end{array}$ & $\begin{array}{l}24(16.7 \%) \\
125(83.3 \%)\end{array}$ & $\begin{array}{l}72(68.5 \%) \\
33(31.5 \%\end{array}$ & 11.364 & $\begin{array}{l}6.234- \\
20.715\end{array}$ & 0.000 \\
\hline $\begin{array}{l}\text { Smoking } \\
\text { Smoker } \\
\text { Non smoker }\end{array}$ & $\begin{array}{l}15(10.1 \%) \\
134(89.9 \%)\end{array}$ & $\begin{array}{l}12(12.5 \%) \\
93(88.5 \%)\end{array}$ & 1.794 & $0.744-4.321$ & 0.188 \\
\hline $\begin{array}{l}\text { Previous } \\
\text { thyroid nodule } \\
\text { Positive } \\
\text { Negative }\end{array}$ & $\begin{array}{c}39(31.6 \%) \\
110(68.4)\end{array}$ & $\begin{array}{c}102(97.1 \%) \\
3(2.9 \%)\end{array}$ & 95.897 & $28.745-319$ & 0.00000 \\
\hline
\end{tabular}

Table (3): comparison between female DTC cases and female cancer free control as regard the studded risk factors.

\begin{tabular}{|c|c|c|c|c|c|}
\hline Characteristics & $\begin{array}{c}\text { Control } \\
(n=119) \\
\text { No }(\%)\end{array}$ & $\begin{array}{c}\text { DTC cases } \\
(n=99) \\
\text { No }(\%)\end{array}$ & $\begin{array}{l}\text { Odds } \\
\text { ratio }\end{array}$ & 95\% CI & $P$ value \\
\hline $\begin{array}{l}\text { Residence } \\
\text { Rural } \\
\text { Urban }\end{array}$ & $\begin{array}{l}87(73.2 \%) \\
32(26.8 \%)\end{array}$ & $\begin{array}{c}58(58.6) \\
41(41.4 \%)\end{array}$ & 1.922 & $1.088-3.396$ & 0.024 \\
\hline $\begin{array}{l}\text { Family history } \\
\text { Positive } \\
\text { Negative }\end{array}$ & $\begin{array}{l}24(20.1 \%) \\
95(79.9 \%)\end{array}$ & $\begin{array}{l}18(18,1 \%) \\
81(81.9 \%)\end{array}$ & 0.880 & $0.446-1.735$ & 0.711 \\
\hline $\begin{array}{l}\text { Obesity } \\
\text { BMI } \geq 25 \\
\text { BMI }<25\end{array}$ & $\begin{array}{l}23(19.3 \%) \\
96(80.7 \%)\end{array}$ & $\begin{array}{l}68(68.6 \%) \\
31(31.4 \%)\end{array}$ & 8.683 & $\begin{array}{l}4.684- \\
16.089\end{array}$ & 0.0000 \\
\hline $\begin{array}{l}\text { Previous } \\
\text { thyroid nodule } \\
\text { Positive } \\
\text { Negative }\end{array}$ & $\begin{array}{l}33(27.7 \%) \\
86(72.3 \%)\end{array}$ & $\begin{array}{c}96(96.6 \%) \\
2(3.4 \%)\end{array}$ & 83.394 & $\begin{array}{l}24.689- \\
281.68\end{array}$ & 0.00000 \\
\hline
\end{tabular}




\section{Discussion}

Increased incidence of DTC in the past three decades had been established by many epidemiological studies, suggesting not only the effect of enhanced diagnosis of previously missed cases, but also true increase which can be attributed to exposure to environmental risk factors. In Egypt, thyroid cancer represents about $1.5 \%$ of all cancers in both sexes and $3.6 \%$ of female malignancy and constitutes about $30 \%$ of endocrine malignancies with overall female to male ratio less than 3 (Freedman et al., 2006). We studded the effect of environmental factors other than the most documented and established known risk of ionizing radiation and low iodine intake which were negative in both cases and controls in the current study.

Among 105 DTC patients who were enrolled in this case control study, $94 \%$ were females although this ratio appear higher than the known previously stated ratio in Egypt, but this can be explained by the fact that this registry was performed five years ago beside in upper Egypt, thyroid cancer account fot $3 \%$ of female cancer representing the fifth most common malignancy in addition to increase in female ration with age which is consistent with our results as more than $65 \%$ of the patients are older than 45 years. Also, this high ratio was documented in nearby country that Saudi. According to the study of Albasri, thyroid cancer has become the second most common tumor in the Saudi women. The male to female ratio in this region is 4:29 (Albasri et al., 2014).

Low iodine intake and its effect in endemic goiter is a proposed risk factor for follicular thyroid cancer. Endemic goiter was reported in Egypt more than 60 years ago. Although most of the nutrition studies on goiter in Egypt have been done in New Valley in the Western Desert, but endemic goiter has also been reported in other regions. According to our results residence in a rural area constitute a significant risk of DTC (P value $<0.05$ ), this was established in both sexes and females only analysis, (OR is 1.643 with $95 \%$ CI of 0.970 to 2.784). Absence of recent studies about endemic goiter in adults in Egypt constituted a difficulty in explaining the effect of residence in thyroid cancer. Although, in Aswan governorate, a rate of $17.5 \%$ in primary-school children (8-10 years) has recently been reported El-Sayed NA et al., 1995).These studies established presence of nutritional issues as regard iodine intake, which can be suggested in Sohag governorate too as an explanation of the effect of residence on cancer occurrence. Another explanation is difference in access to health care between rural and urban areas.

Obesity is a well known risk factor for many cancers, it has been estimated that $6 \%$ of the new cancer in US is attributed to obesity (Polednak et al., 2008).We found that $68.5 \%$ of DTC cases were overweight or obese (BMI 25) compared to $16.7 \%$ of the controls and the difference was very high statistically significant $(\mathrm{P}$ value $=0.000)$. Compared to controls obese women are 11.3 times at higher risk for thyroid cancer. These results are consistent with previous studies (Engeland et al., 2006) (Renehan et al., 2008) and (Kitahara et al., 2011) reported moderate association between obesity and thyroid cancer in both sexes. In addition, results of meta analysis studies also reported that Overweight, obesity and excess body weight were all positively associated with thyroid carcinoma risk in both sexes(Cari et al., 2011) and (ZG ZHAO et al., 2012). As regard DTH risk in obese women, (-Elizabeth et al., 2013) reported that women with thyroid cancer were more likely to be obese (BMI, 225) than women without cancer $(30 \%$ vs. $22 \%, \mathrm{P}=$ $0.004)$ and had a higher mean waist circumference, fat ratio, and blood pressure. These differences were not observed in men. In logistic-regression models adjusted for age, smoking status, and serum TSH level, BMI was a significant predictor of thyroid cancer in women (odds ratio [OR], 1.63; 95\% CI 1.24 to 2.10 ) but not in men (OR, 1.16; 95\% CI, 0.85 to 1.57. these results are consistent with ours ( $68.6 \%$ of the cases vs $19.3 \%$ of the control were obese, $\mathrm{P}$ value $=0.000$ ). while our $\mathrm{OR}$ was much higher (8.683; CI 4.684 to 16.089 ).

Although smoking is a well known risk factors for many malignancies but results from different studies about its effect on thyroid cancer are controversial. We found no statistically 
significant difference between cases of DTC and cancer free controls as regard smoking $(\mathrm{P}$ value $=$ 0.188 ) which is consistent with (Kreiger et al., 2000) and (Bandurska et al., 2012) who found no correlation between cancer and smoking. While (Suzuki et al., 2007), (Meinhold et al., 2010) and (Kabat et al., 2012) found that smoking reduce risk of thyroid cancer. This was explained by the role of Cytochrome P4501A1 (CYP1A1) gene variants that was related to an increased capacity to activate polycyclic aromatic hydrocarbons, producing highly reactive electrophilic intermediates that might damage DNA. The germline inheritance of a wild-type CYP1A1 gene has been thought to decrease the susceptibility for thyroid cancer. (Natassia et al., 2006) performed multivariate logestic regression analysis on thyroid cancer cases and controls and found that The wild-type CYP1A1m1 genotype was more frequent among papillary carcinoma patients $(74.26 \%)$ than in the control population (62.45\%; $\mathrm{P}=0.0147)$, reducing the risk for this type of cancer (odds ratio $=0.564 ; 95 \%$ confidence interval $=0.357-0.894)$.

As regard positive history of thyroid nodule, there was very high statistically significant difference between DTC cases and cancer free control (97\% cases vs $31.6 \%$ control, $\mathrm{P}$ value $<0.0001)(\mathrm{OR}=$ 95.897, 95\% CI: 28.745- 319). These findings are consistent with (Franceschi et al., 1999) and (Shin et al., 2016), the former also reported that the risk for a history of benign nodules/adenomas was especially high $(\mathrm{OR}=29.9,95 \% \mathrm{CI}$ : 14.562.0) in women and in men there were 18 cases versus 0 controls. (Rago et al., 2010) performed multiple logestic regression analysis and found also that solitary thyroid nodule constitute a predictive independent factor for papillary thyroid $(\mathrm{OR}=0.63$, CI 0.547-0.717; $\mathrm{P}<0.0001)$.

We did not found significant difference between cases and control as regard family history ( $\mathrm{P}$ value $=0.82$ ) which is consistent with (Shin et al., 2016) who also recommended that the concept of first-degree family history as a risk factor for thyroid malignancy should be further studied in asymptomatic patients. On the contrary many studies previously documented the role of family history in thyroid cancer occurrence like (Seung et al., 2015) and ( $\mathrm{Li} \mathrm{Xu}$ et al., 2012) who found that having a family history of thyroid cancer increased risk of thyroid cancer (OR 4.39; 95\% CI 1.73-11.15) and (adjusted OR $=4.1,95 \% \mathrm{CI}: 1.7-$ 9.9) respectively. It is well known that having a positive family history of cancer in any cancer patient might be due to both a heredity effect and the sharing of a causative environment. To date, several genes or loci have been reported as possible candidates for the genetic background of differentiated thyroid cancer, but the correlation between these mutations and thyroid cancer remains controversial (Khan et al., 2010). As regard the causative organism, radiation and exposure to radioactive iodine which are well accepted and proved risk factors are negative in all patients in this study and the other studded factors are still suggestible not well established risk factors. Beside, family members of those who give negative family history, it may revealed that they have caner with time with improved access to diagnostic procedure this particularly had been suggested by (T C Gierlowski et al., 1995)who emphasized the problem of underreporting and suggested caution in evaluating family history information derived from interviews for less lethal cancers.

\section{References}

Albasri A, Sawaf Z, Hussainy AS, Alhujaily A (2014). Histopathalogical patterns of thyroid disease in Al-Madinah region of Saudi Arabia. Asian Pac J Cancer Prev, 15, 5565-70.

Amal S. Ibrahim,1 Hussein M. Khaled,2 Nabiel NH Mikhail,3 Hoda Baraka,4 and Hossam Kamel2.Cancer Incidence in Egypt: Results of the National Population-Based Cancer Registry Program, -Journal of Cancer Epidemiology, Volume 2014 (2014), Article ID 437971, 18 pages. http://dx.doi.org/10.1155/2014/437971

Bandurska-Stankiewicz E, Aksamit-Bialoszewska E, Rutkowska J, StankiewiczA \& Shafie D 2011 The effect of nutritional habits and addictions on the incidence of thyroid carcinoma in the Olsztyn province of Poland. Endokrynologia Polska 62 145-150. 
Brindel P, Doyon F, Bourgain C, et al. Family history of thyroid cancer and the risk of differentiated thyroid cancer in French Polynesia. Thyroid. 2010;20(4):393-400.

Cancer. 2012 Mar 1; 118(5): 1228-1235.

Cari M. Kitahara Elizabeth A. Platz , Laura E. Beane Freeman, Ann W. Hsing MarthaS. Linet, Yikyung Park, Catherine Schairer, Arthur Schatzkin, James M. Shikany, and Amy Berrington de González..Obesity and thyroid cancer risk among U.S. men and women: a pooled analysis of 5 prospective studies. Cancer Epidemiol Biomarkers Prev. 2011 March ; 20(3): 464-472. doi:10.1158/10559965.EPI-10-1220.

Carter WB, Tourtelot JB, Savell JG, Lilienfeld H. New treatments and shifting paradigms in differentiated thyroid cancer management. Cancer Control 2011;18:96-103.

Elizabeth N. Pearce, Han JM, Kim TY, Jeon MJ, Yim JH, Kim WG, Song DE, Hong SJ, Bae SJ, Kim HK, Shin MH, Shong YK, Kim WB. Obesity is a risk factor for thyroid cancer in a large, ultrasonographically screened population. Eur J Endocrinol. March 19, 2013

El-Sayed NA et al. Assessment of the prevalence of iodine deficiency disorders among primaryschool children in Cairo. Eastern Mediterranean health journal, 1995, 1:55-63.

Engeland A, Tretli S, Akslen LA, Bjørge T. Body size and thyroid cancer in two million Norwegian men and women. $\mathrm{Br} \mathrm{J}$ Cancer 2006;95:366-70. Epub July 11, 2006.

Franceschi S, Preston-Martin S, Dal Maso L, Negri E, La Vecchia C, Mack WJ, et al. A pooled analysis of case-control studies of thyroid cancer. IV. Benign thyroid diseases. Cancer Causes Control 1999;10:583-95

Freedman LS, Edwards BK, Ries LAG et al. (2006) Cancer incidence in four member countries (Cyprus, Egypt, Israel and Jordan) of the Middle East cancer consortium (MECC) compared with US SEER National cancer institute, NIHPub. No 06-5873. Bethesda, MD. Chapter title; Thyroid cancer (13) pp 120-131. Edited by Ronckers $\mathrm{C}$ and Ron $\mathrm{E}$

Hu MI, Vassilopoulou-Sellin R, Lustig R, Lamont JP. Thyroid and Parathyroid Cancers. In: Pazdur R, Wagman LD, Camphausen KA, Hoskins WJ. eds. Cancer Management: A
Multidisciplinary Approach. 11 eds. Manhasset, NY: CMP Medica, 2008.

Jemal A, Siegel R, Ward E, Hao Y, Xu J, Thun MJ. Cancer statistics, 2009. CA Cancer J Clin. 2009;59:225-49.

Jemal A, Siegel R, Xu J, et al. Cancer statistics, 2010. CA Cancer J Clin. 2010; 60:277-300. [PubMed: 20610543].

Kabat GC, Kim MY, Wactawski-Wende J \& Rohan TE 2012 Smoking and alcohol consumption in relation to risk of thyroid cancer in postmenopausal women. Cancer Epidemiology $36 \quad 335-340$. (doi:10.1016/j.canep.2012.03.013)

Khan A, Smellie J, Nutting C, Harrington K, Newbold K. Familial nonmedullary thyroid cancer: a review of the genetics. Thyroid. 2010;20:795-801. [PubMed

Kitahara CM, Linet MS, Beane Freeman LE et al. Cigarette smoking, alcohol intake, and thyroid cancer risk: a pooled analysis of five prospective studies in the United States. Cancer Causes Control. 2012;23:1615-24.

Kitahara CM, Platz EA, Freeman LE, Hsing AW, Linet MS, Park Y, Schairer C, Schatzkin A, Shikany JM, Berrington de González A. Obesity and thyroid cancer risk among U.S. men and women: a pooled analysis of five prospective studies. Cancer Epidemiol Biomarkers Prev 2011;20:464-72. Epub January 25, 2011.

Korean J Radiol 2016;17(2):255-263

Kreiger N \& Parkes R 2000 Cigarette smoking and the risk of thyroid cancer. European Journal of Cancer 36 1969-1973. (doi:10.1016/S0959- 8049(00)00198-2)

Li Xu, Guojun Li, Qingyi Wei, Adel K. ElNaggarand Erich M. Sturgis. Family History of Cancer and Risk of Sporadic Differentiated Thyroid Carcinoma.

Meinhold CL, Ron E, Schonfeld SJ, Alexander BH, Freedman DM, Linet MS \& Berrington de Gonzalez A 2010 Nonradiation risk factors for thyroid cancer in the US Radiologic Technologists Study. American Journal of Epidemiology $\quad 171 \quad 242-252$. (doi:10.1093/aje/kwp354)

Natassia E Bufalo, Janaina L Leite, Ana C T Guilhen, Elaine C Morari, Fabiana Granja, Ligia V M Assumpcao and Laura S Ward. 
Smoking and susceptibility to thyroid cancer: an inverse association with CYP1A1 allelic variants. Endocrine-Related Cancer (2006) 13 1185-1193

Polednak AP. Estimating the number of U.S. incident cancers attributable to obesity and the impact on temporal trends in incidence rates for obesity-related cancers. Cancer Detect Prev 2008;32:190-9. Epub September 13, 2008.

Rago T, Fiore E, Scutari M, Santini F, Di Coscio G, Romani R, et al. Male sex, single nodularity, and young age are associated with the risk of finding a papillary thyroid cancer on fine-needle aspiration cytology in a large series of patients with nodular thyroid disease. Eur J Endocrinol. 2010;162:763-770. [PubMed[

Renehan AG, Tyson M, Egger M, Heller RF, Zwahlen M. Body-mass index and incidence of cancer: a systematic review and meta-analysis of prospective observational studies. Lancet 2008;371:569-78.

Seung-Kwon Myung, Chan Wha Lee, Jeonghee Lee, MS, Jeongseon Kim, ,Hyeon Suk Kim. Risk Factors for Thyroid Cancer: a HospitalBased Case-Control Study in Korean Adults. Cancer Res Treat. 2016 Jun 23. doi: 10.4143/crt.2015.310

Shin Hye Hwang, Eun-Kyung Kim, Hee Jung Moon, Jung Hyun Yoon, Jin Young Kwak, Risk of Thyroid Cancer in Euthyroid Asymptomatic Patients with Thyroid Nodules with an Emphasis on Family History of Thyroid Cancer.

Stewart BW, Wild CP, editors. World Cancer Report 2014. Lyon, France: International Agency for Research on Cancer; 2014.

Suzuki T, Matsuo K,Wakai K, Hiraki A, Hirose K, Sato S, Ueda R \& Tajima K 2007 Effect of familial history and smoking on common cancer risks in Japan. Cancer 109 2116-2123. (doi:10.1002/cncr.22685)

T C Gierlowski, E Ron, A B Schneider. The accuracy of siblings' family history reports of thyroid and other cancers. American Journal of Public Health: March 1995, Vol. 85, No. 3, pp. 408-409

Wartofsky L. Increasing world incidence of thyroid cancer: increased detection or higher radiation exposure? Hormones (Athens). 2010;9:103-8.

Xu L, Li G, Wei Q, et al. Family history of cancer and risk of sporadic differentiated thyroid carcinoma. Cancer. 2012; 118(5):1228-1235.

ZG ZHAO, XG GUO, CX BA, W WANG, YY YANG, J WANG AND HY CAO. Overweight, Obesity and Thyroid Cancer Risk: a Meta-analysis of Cohort Studies. The Journal of International Medical Research .2012; 40: $2041-2050$

Zhao ZG, Guo XG, Ba CX et al. Overweight, obesity and thyroid cancer risk: a metaanalysis of cohort studies. J Int Med Res. 2012;40:2041-50.

\begin{tabular}{|c|c|}
\hline \multicolumn{2}{|c|}{ Access this Article in Online } \\
\hline \multirow{2}{*}{ 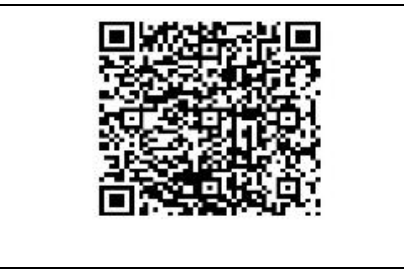 } & $\begin{array}{l}\text { Website: } \\
\text { www.ijcrims.com }\end{array}$ \\
\hline & $\begin{array}{l}\text { Subject: } \\
\text { Medicine }\end{array}$ \\
\hline Quick Response Code & \\
\hline
\end{tabular}

\section{How to cite this article:}

Rasha Abd Elhameed Ali Mohamed, Raafat Abd Elaal Backeet, Wafaa Abd Elhameed Elsaayed. (2016). Risk factors of differentiated thyroid cancer in Sohag, Egypt. Int. J. Curr. Res. Med. Sci. 2(11): 27-34. DOI: http://dx.doi.org/10.22192/ijcrms.2016.02.11.003 